\title{
Microbiology of Seawater and Sand in a Selected Bathing Site of Sri Lanka - A Study Towards Microbial Quality Assessment
}

\author{
Kaumadi Samarasekera, Sriyanie Indrika Abeygunawardena* \\ Department of Microbiology, Faculty of Science, University of Kelaniya, Kelaniya, Sri Lanka \\ Email address: \\ samarasekerak@yahoo.com (K. Samarasekera), indrikaab@gmail.com (S. I. Abeygunawardena) \\ ${ }^{*}$ Corresponding author
}

\section{To cite this article:}

Kaumadi Samarasekera, Sriyanie Indrika Abeygunawardena. Microbiology of Seawater and Sand in a Selected Bathing Site of Sri Lanka - A Study Towards Microbial Quality Assessment. Frontiers in Environmental Microbiology. Vol. 3, No. 1, 2017, pp. 9-18.

doi: $10.11648 /$ j.fem.20170301.12

Received: October 6, 2016; Accepted: January 12, 2017; Published: May 8, 2017

\begin{abstract}
The presence of many types of microorganisms, including potential pathogens has been reported as an integral part of coastal management programs in many countries. Therefore the purpose of this study was to examine the seawater collected from a selected bathing site in the West coast of Sri Lanka, for pollution indicating bacterial parameters. Sand samples were subjected to similar evaluation. Two sites were selected from this location to collect samples. The following microbial parameters were analyzed in the collected samples: enterococci, total coliforms, thermotolerant coliforms, E. coli, Pseudomonas $s p$. and Staphylococcus $s p$. In addition, physical parameters such as temperature, $\mathrm{pH}$ and conductivity were also measured in collected samples. Enterococci counts generally varied from $09-<1600$ (MPN/100 ml). The statistical analysis revealed that counts of enterococci, coliforms, thermotolerent coliforms and $E$. coli were not significantly different at two sites in both seawater and sand samples. The average enterococci and total coliform counts in beach sand were higher than that of seawater. However, E. coli showed a higher average count as $228(\mathrm{MPN} / 100 \mathrm{ml})$ in seawater than $72(\mathrm{MPN} / 100 \mathrm{ml})$ in beach sand. Bacteria belonging to species of Vibrio, Aeromonas, Pseudomonas, Bacillus, Staphylococcus and Listeria were identified from both seawater and sand. The sampled seawater was characterized by a salinity of 20-33 (ppt) and varying pH of $6.7-$ 8.20. Based on the obtained results for enterococci, the selected location was provisionally classified in the D category as per WHO guidelines. However microbiological quality of the seawater as per the water quality guidelines depends upon which indicator microbe is chosen.
\end{abstract}

Keywords: Microbial Quality of Seawater \& Sand, Enteroccocus, Coliforms, E. coli

\section{Introduction}

Beach quality monitoring and assessments based on microbiological, physical and chemical parameters are considered as a vital part of coastal management programs due to the increased recreational activities. The problem of seawater pollution is therefore acknowledged worldwide and many countries are already monitoring the quality of beaches according to national and/or international standards; Australia [1], Brazil [2], Greece [3], Portugal [4], New Zealand [5], United Kingdom [6], United States [7], etc. The contamination of beach sand and seawater has increased due to improper garbage disposal, discharge of untreated domestic sewage, animal waste, pollution that are brought by rain water and river water [2]. The recreational water generally consists of pathogenic and non-pathogenic microorganisms derived from various sources. It has been found that these pathogens has the ability to cause many health problems such as gastrointestinal, respiratory, skin, eye, nasal cavity and ear infections, etc., who use these areas for their recreational activities [8, 9]. Since continuous epidemiological studies have shown a gradual increase in these diseases among the bathers, many countries have considered that it is important to monitor the microbiological quality of seawater and beach sand. World Health Organization [10] and United States Environmental 
Protective Agency (US-EPA) [11] have setup guidelines to assess the microbiological quality of seawater and to grade the beaches according to the quality seawater.

The microbiological quality of beach sand, specially the sand - water interface is receiving more attention as high levels of fecal indicator bacteria have been detected during several studies [7, 12]. In a study carried out in Oak Creek, Arizona, USA reported, a fecal coliform count in sand was 2200 times higher than that of seawater [13]. Results revealed that re-suspension of sand due to recreational activities have affected the quality of seawater in a negative manner [13]. Based on research findings, sand is considered as a reservoir of infection in beaches $[2,14]$. Generally most of the recreational users of beaches, especially the children are in contact with beach sand more than seawater, but still the legislations or guidelines have not been set up to assess the quality of beach sand [14].

According to many reported studies, the assessment of microbiological quality of beaches is based on the assessment of fecal pollution due to its adverse effect on recreational water users. The indicator organisms are used as a fundamental monitoring tool to measure both changes in water quality and to find the potential of presence of pathogens that cannot be easily detected [8]. The recommended indicator organism for marine water is Enterococcus [10]. Many studies have reported the presence of Enterococcus spp., Aeromonas spp. Staphylococcus spp., Pseudomonas spp., E. coli, etc. in either beach sand or sea water or in both samples [14 -16] which have the ability to cause infections in humans. The presence of fungi and yeasts were also reported in seawater and sand [17-19].

Sri Lanka is an island where tourism is one of the major economic sectors in its economy. The beaches therefore play a major role as recreational environments which make it important to assess the quality of these beaches. At the local level, few studies have been carried out [20]. However, no preliminary studies have been carried out to provide the foundation to classify the beaches according to international standards.

This study was carried out to provide a foundation which would be helpful to the local responsible authorities and other interested parties in their future research on assessing microbiological quality of Sri Lankan beaches. The primary objective of the current study was to evaluate microbiological quality of the seawater of a selected beach site. The evaluation focused on Enterococcus, Total coliforms, Thermotolerant coliforms, E. coli, Pseudomonas and Staphylococcus. The wet sand collected from the beach area was also monitored for its microbial consortium.

\section{Materials and Methods}

\subsection{Selection of Sampling Site}

The bathing location at Prithipura area, Hendala (a part of Uswatakeiyawa Beach) in the Western province of Sri Lanka was chosen as the study site. From this location, two sites with the highest bathers' density were selected and these two sites were located approximately $150 \mathrm{~m}$ away from each other. The Table 1 illustrates the location with its landmarks around it. The distance for the two prominent landmarks from the selected site is as follows; $6.8 \mathrm{Km}$ to Colombo Dockyard and $1.2 \mathrm{Km}$ for the Dikkowita fisheries harbor. This selected beach area is visited by locals as well as foreigners and several resorts, hotels, houses, etc. are also located in this area.

Table 1. Distance to landmarks from bathing location.

\begin{tabular}{ll}
\hline Landmark & Distance from location $(\mathbf{k m})$ \\
\hline Colombo Dockyard & 6.80 \\
Pegasus Beach hotel & 0.45 \\
Dikkowita fisheries harbour & 1.20 \\
\hline
\end{tabular}

\subsection{Sample Collection and Preparation}

Samples of seawater from $0.3 \mathrm{~m}$ below the water surface and beach sand (wet sand) from the shoreline were collected from April 2015 to September 2015 at different time intervals. The sampling was performed according to the guidelines given by American Public Health Association [21] where seawater samples were collected into sterilized amber coloured polyethylene bottles $(200 \mathrm{ml})$ and sand into sterile polyethylene zipped bags. From each site, samples were obtained from three places with $20 \mathrm{~m}$ distance between each other. The samples were transported to the laboratory in a cool box.

Composite samples of both seawater and beach sand were prepared for the two sites separately. Equal amounts from the three samples collected at each site were mixed well to prepare the composite samples.

Extraction of beach sand

Sand $(50 \mathrm{~g})$ from the composite sample was placed in a pre-sterilized glass bottle $(300 \mathrm{ml})$ into which Phosphate Buffer Saline (PBS) eluent $(120 \mathrm{ml})$ was added and shaken for 2 minutes by hand over an arc of about $10 \mathrm{~cm}$, following a 30 seconds settling time. The supernatant was decanted into a second sterile bottle. An additional PBS $(80 \mathrm{ml})$ was again added to the sand and the bottle was gently swirled for 10 seconds after which the bottle was allowed to settle for 30 seconds. The supernatant was then transferred into the same sterile bottle used after the first rinse step.

\subsection{Detection and Enumeration of Enterococcus}

Multiple tube technique was followed for both seawater and sand, and the test was performed according to APHA [21]. During the presumptive test, the samples were inoculated into tubes of Azide dextrose broth and incubated at $37^{\circ} \mathrm{C}$ for $48 \mathrm{~h}$. All the positive tubes were sub-cultured into Bile Esculin Agar for confirmation and incubated at $37^{\circ} \mathrm{C}$ for $24 \mathrm{~h}$. For further confirmation, the isolated colonies were transferred to tubes of Brain Heart Infusion broth with $6.5 \% \mathrm{NaCl}$ and incubated at $35 \pm 0.5^{\circ} \mathrm{C}$ and into another tube of brain-heart infusion broth which was incubated at $45 \pm 0.5^{\circ} \mathrm{C}$. 


\subsection{Detection and Enumeration of Total Coliforms, Thermotolerant Coliforms and E. coli}

The multiple tube technique was followed with a slight modification to the protocol described in APHA [21]. Lactose broth [22] was used to perform the presumptive test. Tubes of Lactose Broth were inoculated and incubated at $37^{\circ} \mathrm{C}$ for $48 \mathrm{~h}$. The positive tubes were transferred into the Brilliant Green Lactose Bile (BGLB) broth and to the EC broth separately for the detection of Total Coliforms (incubated at $37^{\circ} \mathrm{C}$ for $48 \mathrm{~h}$ ) and Thermotolerant Coliforms (incubated at $44^{\circ} \mathrm{C}$ for $48 \mathrm{~h}$ ) respectively.

The positive EC broth tubes were then inoculated into tubes of Tryptone broth and incubated at $44^{\circ} \mathrm{C}$ for $24-48 \mathrm{~h}$. The Indole test was performed for these tubes after incubation to detect and enumerate $E$. coli.

\subsection{Quantitative Estimation of Staphylococcus aureus and Pseudomonas spp}

Mannitol Salt Agar and Pseudomonas Selective Agar were used to enumerate $S$. aureus and Pseudomonas respectively and the followed methods were similar to that of given in previous studies $[14,23]$. The inoculated plates were incubated at room temperature for $60 \mathrm{~h}$.

During the enumeration and/or detection of different bacteria, quality controlling of the performed tests were carried with following reference bacterial cultures; i.e. Enterococcus faecalis (DBUMK 157011), E. coli (DBUMK 30019), Staphylococcus aureus (DBUMK 96017) and Pseudomonas aeruginosa (DBUMK 10018). These reference cultures were obtained from the Microbial Culture collection of the Department of Microbiology, Faculty of Science, University of Kelaniya. The culture media used in this study belonged to the following brands; Oxoid, Sigma and Himedia.

\subsection{Enumeration, Isolation and Identification of Heterotrophic Bacteria}

For both seawater and sand samples, the serial dilution plate technique was used. Nutrient Agar with 3\% $\mathrm{NaCl}$ and Plate Count Agar with $1 \% \mathrm{NaCl}$ were used to isolate halotolerant bacteria from seawater and sand samples respectively. All the plates were incubated at $28^{\circ} \mathrm{C}$ for $24 \mathrm{~h}$. The morphologically different colonies from the serial dilution plate technique were isolated for identification. The isolated colonies were streaked on Marine Agar supplemented with minimal medium i.e. Vaatanen Nine Salt Solution to obtain pure cultures of different bacteria.
Identification of isolated bacteria was based on their morphological and biochemical studies as given in Bergey's manual volume 1 [24] and volume 2 [25], Manual of Medical Microbiology [26], Prokaryotes - A Hand book of Biology of bacteria volume 4 and $6[27,28]$ and Harrigan and McCance [29].

\subsection{Measurement of Physical Parameters}

Dissolved Oxygen (DO) content, $\mathrm{pH}$, Total Dissolved Solids (TDS), conductivity and salinity were measured as physical parameters using HACH HQ40d Multi-parameter, to assess the variation of these parameters during the sampling period. DO was measured only in seawater samples. Temperature was measured at the sampling location.

To measure the physical parameters in sand, $25 \mathrm{~g}$ was added into $100 \mathrm{ml}$ of deionized water and shaken vigorously for 2 minutes. Then the sand was allowed to settle for a further 2 minutes and the physical parameters were monitored immediately.

\section{Results and Discussion}

The location (Preethipura, Uswetakeiyawa beach) was selected to carry out the research because of its attractiveness as a bathing beach in the area. The sampling period was from April to September 2015 which is the Southwest monsoon season of Sri Lanka [30]. As the selected location is situated in the west coast of the country, a windy weather with rain and on some days a rough sea was experienced (visual observations). The sampling was performed generally in the morning time at around 9.30$11.00 \mathrm{am}$. It was observed that high numbers of bathers were present during this time period in this selected location. The indicators given in US-EPA (1986) and WHO (2003) were used to assess the microbiological quality of the seawater in this selected beach. Those indicators were Enterococcus, thermotolerant coliforms (fecal coliforms) and total coliforms.

The sand and seawater collected from the selected locations exhibited variations in all the tested microbiological parameters. The statistical analysis (2sample t-test) indicated that results obtained for all the microbial parameters and physical parameters of Site 1 were not significantly different from Site 2 . But the results were reported as average values of each microbiological parameter and indicating minimum and maximum values of each study site (Tables 2 and 3 ).

Table 2. Summary of the results of microbiological parameters - Seawater.

\begin{tabular}{llll}
\hline Microorganisms & Seawater & Site 1 min - max & Site 2 min - max \\
\hline Enterococcus spp. $(\mathrm{MPN} / 100 \mathrm{ml})$ & $9.0-<1600$ & $1.1 \times 10^{2}-<1600$ & $4.0-<1600$ \\
Coliforms (MPN/100ml) & $23-<1600$ & $23-<1600$ & $23-<1600$ \\
Thermotolerant coliforms (MPN/100ml) & $18-920$ & $23-<1600$ & $13-<1600$ \\
E. coli $(\mathrm{MPN} / 100 \mathrm{ml})$ & $6.0-220$ & $8.0-2.4 \times 10^{2}$ & $8.0-2.2 \times 10^{2}$ \\
Pseudomonas spp. $(\mathrm{cfu} / \mathrm{ml})$ & $1.53 \times 10^{3}-2.28 \times 10^{4}$ & $3.05 \times 10^{3}-8.1 \times 10^{3}$ & $1.90 \times 10^{2}-4.35 \times 10^{4}$ \\
Staphylococcus spp. $(\mathrm{cfu} / \mathrm{ml})$ & $\mathrm{ND}-9.62 \times 10^{3}$ & $\mathrm{ND}-7.35 \times 10^{3}$ & $\mathrm{ND}-9.1 \times 10^{3}$ \\
\hline
\end{tabular}


Table 3. Summary of the results of microbiological parameters - Sand.

\begin{tabular}{llll}
\hline Microorganisms & Sand & Site 1 min - max & Site 2 min - max \\
\hline Enterococcus spp. (MPN/100ml) & $28-<1600$ & $23-<1600$ & $33-<1600$ \\
Coliforms (MPN/100ml) & $40-<1600$ & $50-<1600$ & $30-<1600$ \\
Thermotolerant coliforms (MPN/100ml) & $37-975$ & $50-<1600$ & $23-3.5 \times 10^{2}$ \\
E. coli $($ MPN/100ml) & $18-132$ & $23-220$ & $13-220$ \\
Pseudomonas spp. (cfu/ml) & $7.83 \times 10^{3}-6.12 \times 10^{4}$ & $1.36 \times 10^{4}-6.2 \times 10^{4}$ & $2.06 \times 10^{3}-6.48 \times 10^{4}$ \\
Staphylococcus spp. (cfu/ml) & $4.80 \times 10^{2}-2.52 \times 10^{4}$ & $4.00 \times 10^{2}-3.42 \times 10^{4}$ & $5.60 \times 10^{2}-2.52 \times 10^{4}$ \\
\hline
\end{tabular}

\section{Microbiological parameters - Seawater}

Enterococcus

Enterococci counts generally varied from 4-220 (MPN/100 $\mathrm{ml}$ ) in site 1 , whereas $4-130(\mathrm{MPN} / 100 \mathrm{ml})$ in site 2 (Figure 1 and Table 2) with few exceptional results; i.e. the counts were $>1600$ (MPN/100 ml) (Figure 1). However the combined mean of Enterococcus count in seawater was 294 $/ 100 \mathrm{ml}$. The US-EPA [11] guide has given standard values as a monthly average (geometric mean) of $\leq 35 / 100 \mathrm{ml}$ and $\leq$
$104 / 100 \mathrm{ml}$ on a single day sample for Enterococcus. The results indicated that $65 \%$ of the obtained data was less than $104 / 100 \mathrm{ml}$ on a single day sample.

Since this particular location has neither sanitary inspection data nor microbiological water quality, this location is subjected to provisional classification as given by WHO guide [10]. The obtained results were also treated as a single day sample because of the sampling intervals was not same as given in the WHO guide [10].

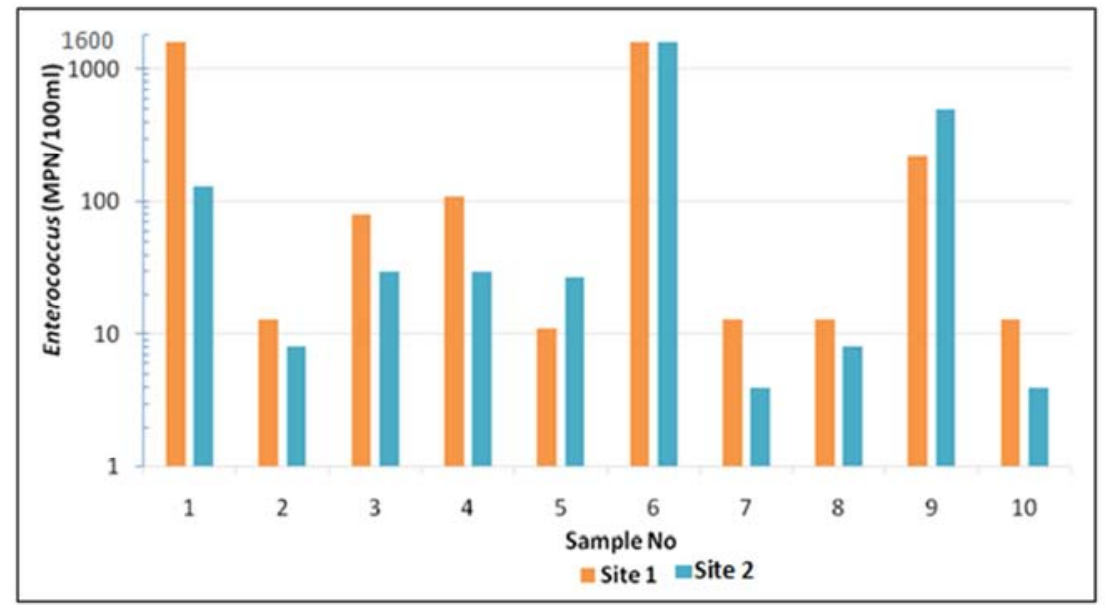

Figure 1. Variations of Enterococcus counts in seawater collected from the two sites selected from the beach area.

Enterococcus spp. is generally considered as the indicator microorganism in international standards such as WHO [10] and US-EPA [31] to evaluate the microbiological quality of marine waters. US-EPA [11] recommends measuring culturable Enterococcus either following the method given by this authority or equivalent method for marine recreational water. The microbiological quality of the collected seawater was therefore initially analyzed using enterococci values.

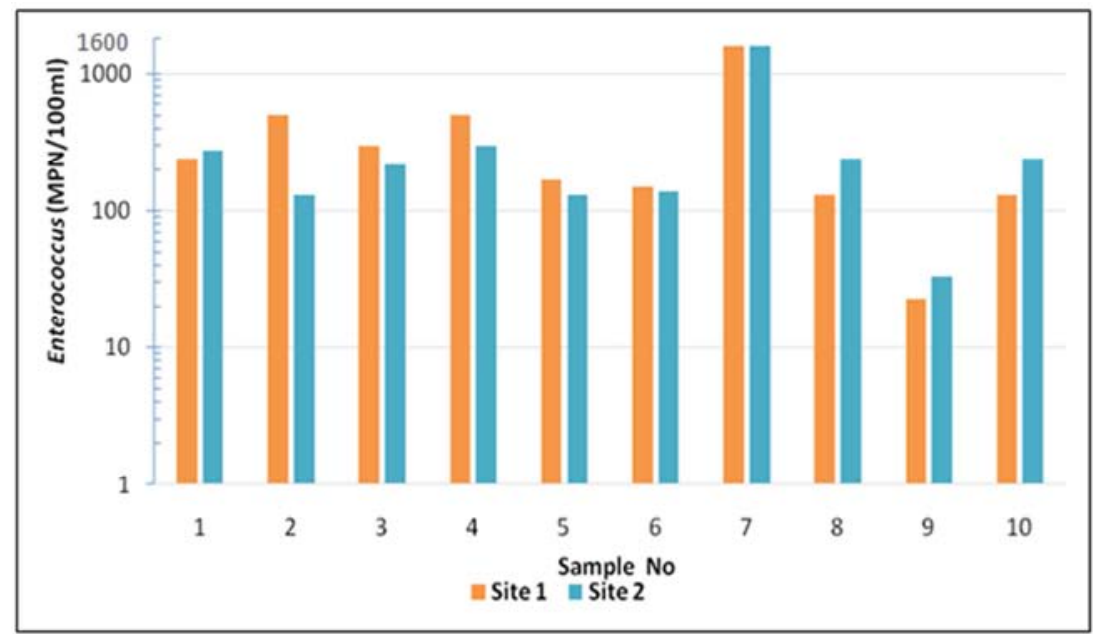

Figure 2. Variations of Enterococcus counts in sand collected from the two sites selected from the beach area. 
The data obtained for this location indicated that $95^{\text {th }}$ percentile value for the Enterococcus count was 1270/100 $\mathrm{ml}$ and this particular location was assigned to the group D as given in the WHO classification [10]. Due to the prevailed weather conditions, very high values of Enterococcus counts were recorded in some sampling dates and such situations were considered as 'exceptional circumstances' and recalculated the $95^{\text {th }}$ percentile value. Under such circumstances, the 95th percentile value of the Enterococcus count was 665/100 $\mathrm{ml}$ and the assigned group was not changed. Based on this classification on beaches, there may be a $10 \%$ of Gastro intestinal illness risk and $3.9 \%$ of acute febrile respiratory illness (AFRI) risk for the users of such beaches. Since an epidemiological study has not been carried out during this research, it is not possible to confirm the related health risks as per the WHO classification [10]. Another important factor is that there is no complete study carried out or available past data to evaluate the suitability of applying this classification for the local beaches. However, under this particular provisional classification, it indicates that there is a fecal contamination in water and it is necessary to follow the sanitary inspection and monitor the sewage discharges, riverine discharges and other possible sources that can increase the fecal contamination.

The results of enterococci in seawater were also assessed according to the US-EPA [31] guidelines. This particular guideline indicates the enterococci level as $\leq 104$ enterococci/100 $\mathrm{ml}$ at $75^{\text {th }}$ percentile for single day samples. The calculated results of enterococci (288 enterococci $/ 100 \mathrm{ml}$ $-75^{\text {th }}$ percentile) indicated that it exceeded the EPA standards for single day samples.

The observed high count of Enterococcus in seawater may be due to the large amount of fecal contaminations coming through the discharge of wastewater from hotels, resorts and residencies and riverine discharges of Kelani River which falls into sea $2.5 \mathrm{~km}$ away from the location. The increased rainfall received during the sampling period which would have increased the surface runoffs, urban storm water overflows and/or re-suspension of sediments might have increased the contaminants in the seawater.
When considering re-suspension of sediments it has been mentioned by Byappanahalli et al. [32], that sediments play a major role in influencing the surface water because of the re-suspension of the particle bound bacteria among which $80 \%$ are fecal streptococci and fecal coliforms. These facts also indicate that the time period that research was carried out was ideal as the highest possible contamination of seawater and highest expected public health risk could occur during this period due to the rainfall.

Total Coliforms, Thermotolerant coliforms and E. coli

In the absence of past data, it is useful to make use of another index organism (or organisms) before any conclusions are made as to the appropriate classification [10]. For this purpose, the two commonly used organisms given in US-EPA [31] guide were used. They are thermotolerant (Fecal) coliforms and total coliforms. E. coli is considered as the most suitable index of fecal contamination in fresh water, but not for marine water [33]. In most circumstances, populations of thermotolerant coliforms are composed predominantly of $E$. coli and as a result, this group is regarded as a less reliable but acceptable index of fecal pollution. However, the presence of $E$. coli and thermotolerant coliforms provides evidence of fecal contaminations in selected location.

The thermotolerent coliform counts and $E$. coli counts for seawater were positively correlated in site $01(\mathrm{r}=0.672, \mathrm{p}=$ 0 . 033) and site $02(\mathrm{r}=0.983, \mathrm{p}=0.000)$. During the study, it was observed that thermotolerant coliform counts were ranged from 18 to $920(\mathrm{MPN} / 100 \mathrm{ml})$ in seawater, whereas E coli varied from 6.0 to 220 (MPN/100 ml) (Table 2). The calculated data indicated that this location is characterized by the geometric mean for each indicator bacterial group i.e total coliforms - $867 \mathrm{MPN} / 100 \mathrm{~mL}$, thermotolerant coliforms - $380 \mathrm{MPN} / 100 \mathrm{~mL}$, E. coli - $253 \mathrm{MPN} / 100 \mathrm{~mL}$. These values of coliforms and thermotolerant coliforms were below the regulatory guidelines for recreational water given by USEPA [31] i.e. coliforms $\leq 2400 / 100 \mathrm{ml}$ and thermotolerant coliforms $\leq 800 / 100 \mathrm{ml}$ on a single day (Table 4).

Table 4. Guidelines for recreational marine water recommended or implemented by USEPA - (Shibata et al., 2004).

\begin{tabular}{lll}
\hline Indicator microbe & Guidelines & Developed or utilized by: \\
\hline E. coli & Not recommended for marine waters. For freshwater a geometric mean of $\leq 126 / 100 \mathrm{ml}$ and $\leq$ \\
& $235 / 100 \mathrm{ml}$ on a single day. \\
Enterococci & A geometric mean of $\leq 35 / 100 \mathrm{ml}$ and $\leq 104 / 100 \mathrm{ml}$ on a single day. \\
Fecal coliform & A monthly average (geometric mean) of $\leq 200 / 100 \mathrm{ml}, \leq 400 / 100 \mathrm{ml} \mathrm{in} 10 \%$ of samples, and \\
& $\leq 800 / 100 \mathrm{ml}$ on a single day. \\
Total coliform & A monthly average (geometric mean) of $\leq 1000 / 100 \mathrm{ml}, \leq 1000 / 100 \mathrm{ml}$ in $20 \%$ of samples, and $\leq$ \\
\hline
\end{tabular}

After evaluating the enterococci as the bacterial indicator to assess the seawater, the selected location was provisionally classified as D grade level beach. Since there is no guideline to assess the quality of beaches in Sri Lanka, the obtained data also compared with the water quality classification criteria of Brazilian Legislation CONAMA 274/2000 as given by Ribeiro [34] (Table 5). 
Table 5. Water quality standards of Brazilian legislation CONAMA 274/2000 (MPN/100ml) (Ribeiro et al., 2002).

\begin{tabular}{|c|c|c|c|c|c|}
\hline \multirow{3}{*}{ Parameter } & \multicolumn{5}{|c|}{ Water (MPN/100ml) } \\
\hline & \multicolumn{3}{|c|}{ Proper Category } & \multirow[t]{2}{*}{ Inappropriate } & \multirow{2}{*}{ Results of the present study } \\
\hline & Excellent & Very good & Satisfactory & & \\
\hline Fecal coliforms & $<2.5 \times 10^{2}$ & $<5.0 \times 10^{2}$ & $<1.0 \times 10^{3}$ & $>2.5 \times 10^{3 *}$ & $3.80 \times 10^{2}$ \\
\hline E. coli & $<2.0 \times 10^{2}$ & $<4.0 \times 10^{2}$ & $<8.0 \times 10^{2}$ & $>2.0 \times 10^{3 *}$ & $2.53 \times 10^{2}$ \\
\hline Enterococci & $<25$ & $<50$ & $<1.0 \times 10^{2}$ & $>4.0 \times 10^{2^{*}}$ & $3.10 \times 10^{2}$ \\
\hline
\end{tabular}

* Last sample value

As per Brazilian guidelines (Table 5), if ranking is based on E. coli and thermotolerant coliforms, the studied beach can be classified into the category of 'Very good'. When enterococci were considered as the indicator organism for water quality, it was observed that microbial concentration was higher than that of the referred legislation limits for 'Satisfactory level', but less than the category of 'Inappropriate level'. However it appears that the results are more towards the level of 'Inappropriate'. Therefore, according to both guidelines; i.e. US-EPA and Brazilian Legislation, this studied beach area is susceptible to fecal pollution with some potential pollution sources and attention must be paid to control such sources. The results also indicated that different ratings or levels of classification can be obtained for the same beach water depending upon the selected indicator organism. The three guidelines used to compare the data in this study were WHO [10], US-EPA [11, 31] and Brazilian Legislation CONAMA 274/2000 [34]. When Enterococcus is used as the indicator organism, the microbial quality of seawater is 'poor' as per all three guidelines. But change of the indicator organism to total coliforms and/or to thermotolerant coliforms, the quality of seawater was moved to a different quality level as per USEPA and Brazilian Legislation. However WHO guidelines do not indicate any other bacterium other than Enterococcus. Similar findings have been reported by other researchers [34, 35]. These indicator organisms can inactivate due to sunlight and it has been shown that enterococci degrade more rapidly than E. coli [36]. Therefore selection of indicator organisms for tropical waters should be done after carrying out a systematic study with a large set of data. It also appears that multiple indicator organisms may be useful in assessing the microbiological quality of seawater, but indicator levels should be given after analyzing many data sets.

\section{Pseudomonas and Staphylococcus}

According to the reported results for seawater, Pseudomonas counts were varying with an average of $1.53 \times 10^{3}-2.28 \times 10^{4}(\mathrm{CFU} / \mathrm{ml})$ (Table 2). During this study period $S$. aureus was not detected in many samples of seawater and sand. Only $45 \%$ of sand samples and $30 \%$ of seawater samples gave positive results. The data showed that S. aureus counts were in a range of ND (not detected) -9.62 $\mathrm{x} 10^{3}(\mathrm{CFU} / \mathrm{ml})$ in seawater.

Regular monitoring of waterborne pathogens is essential to protect public health. Pseudomonas has become an important organism for studying in the marine environment because of the role it plays during the contamination of recreational waters and seawater, as well as outbreaks of opportunistic
Pseudomonas infections [37]. However there are no national or international guideline levels for Pseudomonas and Staphylococcus in marine water. But many studies have shown the importance of Pseudomonas in assessing marine water quality. Yoshpe-purer and Golderman [37] demonstrated that total and fecal coliforms correlated with presence of $P$. aeruginosa in bathing beaches. A moderate positive correlation between three indicator organisms (i.e. fecal coliforms, E. coli and Enterococcus) and St. aureus has been shown in Croatian beaches by Solic and Krstulovic [38]. They have suggested that Pseudomonas and Staphyloccocus aureus can be used as supplementary indicator organisms because it will add valuable information on the sanitary quality of the seawater. However, TugrulIcemer and Topaloglu [23] found a strong correlation between Salmonella and Pseudomonas and they have suggested this could be considered as a good indicator for the fecal pollution of the beach sand but not in water.

The statistical analysis indicated that there was no correlation between Pseudomonas and three indicator organisms; i.e. Fecal coliforms, Total coliforms and Enterococcus as well as between Pseudomonas and E. coli in seawater. Insufficient data may be one of the reasons for not showing any correlation among the microbial parameters as reported by other researchers.

\section{Microbiological parameters - Sand}

During this research, hand-shaking method was followed to extract the microorganisms from sand samples which have been proven to be an efficient method [39]. This method has also been used in previous studies [33, 40].

The sand samples collected from site 1 and site 2 indicated that enterococci counts ranged from $23-500$ and $33-300$ (MPN/100 ml) respectively (Table 3). Comparison of enterococci counts in sand and seawater indicated that a high number of organisms were present in the sand samples irrespective of the site (Figures 1 and 2). The calculated results indicated that Enterococcus in sand would be 1412 MPN/100 g which is higher than the density at Avalon Beach (310 MPN/100 ml) [32] and lower than the values recorded for some sites in the Camburi beach in Brazil [34].

The high counts of enterococci in beach sand may be due to the residual flora remaining as biofilms but unable to replicate due to environmental stresses, transient flora from wetting by seawater, seeding by birds and other sources and surface runoff during rain [32, 41, 42]. Shibata et al. [33] have reported that beach sand can act as a source of Enterococcus in seawater which is also proven by bathers acting as carriers during recreational activities where a bather 
may carry $6 \times 10^{5}$ enterococci into seawater through sand particles adhered to the body [43].

The results indicated that Total coliform counts exceeded the $1600(\mathrm{MPN} / 100 \mathrm{ml})$ in $70 \%$ of sand samples collected from both sites. However lesser number $(40 \%)$ of seawater samples exceeded this value. The results also indicated that Total coliform counts in sand were higher than that of seawater, but $E$. coli counts were high in seawater.

E. coli in sand also showed a correlation with thermotolerent coliforms at Site $1(\mathrm{r}=0.625, \mathrm{p}=0.05)$ as well as at Site $2(\mathrm{r}=0.700, \mathrm{p}=0.024)$. The high counts of coliforms, thermotolerent coliforms and E. coli in sand may indicate that seawater is contaminated by sewage and other pollutants. The survival and re-growth of these indicator bacteria due to the unique environmental conditions found within the shoreline zone is also possible factors that may contribute to the high counts [33].

\section{Heterotrophic bacteria in seawater and sand}

The heterotrophic counts were also monitored using Plate count agar supplemented with $1 \% \mathrm{NaCl}$. In sand samples, the average heterotrophic counts varied from $8.3 \times 10^{1}-6.8 \times$ $10^{3}(\mathrm{CFU} / \mathrm{ml})$. Generally it appeared that the sand samples contain more heterotrophic bacterial counts than the seawater samples (Table 2). In seawater samples the highest recorded heterotrophic counts at Site 1 was $3.38 \times 10^{3}(\mathrm{CFU} / \mathrm{ml})$ and lowest was $1.03 \times 10^{2}(\mathrm{CFU} / \mathrm{ml})$ while at Site 2 , the highest and the lowest values were recorded as $3.88 \times 10^{3}(\mathrm{CFU} / \mathrm{ml})$ and $1.55 \times 10^{2}(\mathrm{CFU} / \mathrm{ml})$ giving an average range of $1.52 \mathrm{x}$ $10^{2}-6.46 \times 10^{4}(\mathrm{CFU} / \mathrm{ml})$.

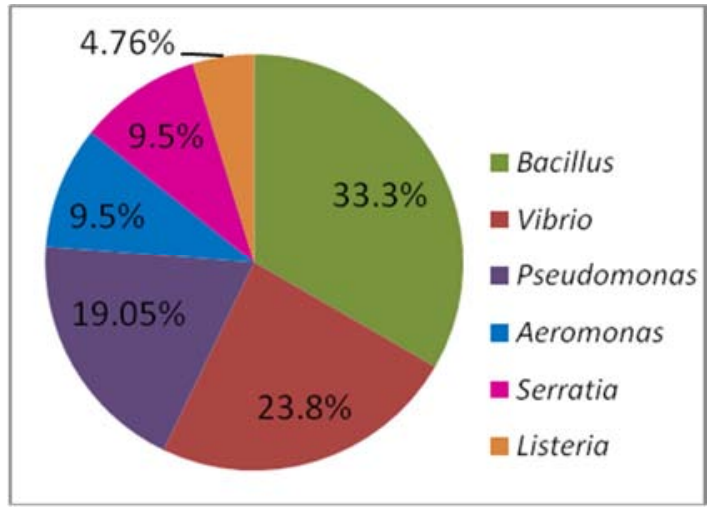

Figure 3. Distribution of some genera in seawater.

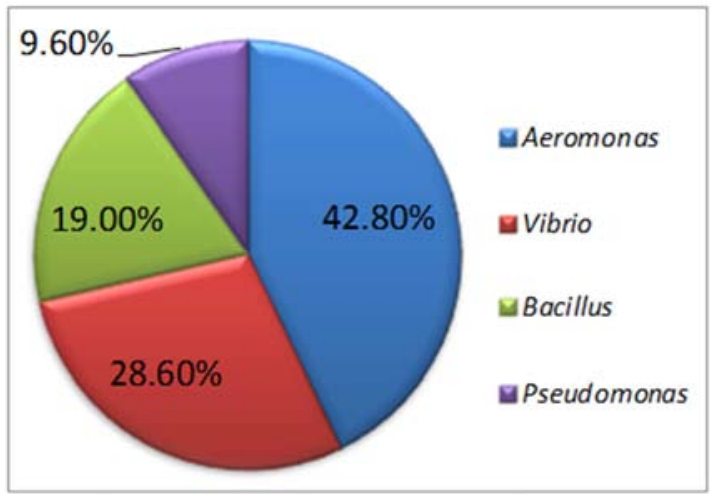

Figure 4. Distribution of some genera in sand.
During this study, a large number of heterotrophic culturable bacteria was isolated, but morphologically varied, total of 52 isolates were subjected to the identification programme. From these isolates, 54\% obtained from seawater. Results also indicated that the $46 \%$ isolates subjected to the identification programme from seawater were gram positives whereas in sand $71 \%$ was gram negative bacteria. These isolates were identified on the basis of their morphological and biochemical characters, but they were not subjected to the molecular basis identification. Therefore those isolates were only identified up to their genus levels. These results are limited to the media used in this experiment and therefore treated cautiously. It is also important to mention that Enterococcus, coliform group of bacteria and Staphylococcus were not included in this experiment and more emphasis was given to Aeromonas, Pseudomonas, Vibrio, Bacillus, Listeria and Serratia. The results indicated lower percentage (10\%) of Aeromonas sp. in seawater (Figure 3) than in sand (43\%) (Figure 4). Bacillus species indicated the highest percentage i.e. $33 \%$ in sea water. In both seawater and sand, the second largest group was Vibrio $s p$ (Figures $3 \& 4$ ).

Aeromonas have been isolated from different aquatic environment including fresh water, brackish water and sea water [44 - 46]. This organism is considered as a halotolerant organism and it can grow at $3 \% \mathrm{NaCl}$ where the salt concentration is very much similar to that of seawater [47]. According to Arias et al. (1999) [48] vibrios constitute a significant part of the autochthonous culturable marine bacteria that comprise several important pathogens of aquatic organisms. It has been reported that population of vibrios changes with the temperature of seawater; increasing with warmer temperatures and algal blooms and decreasing with cooler temperatures. The other organisms isolated from seawater were Pseudomonas and Listeria (Figure 3). Pseudomonas indicated a higher percentage in sea water than in sand. During this study Serratia and Listeria were not detected in sand.

\section{Physical parameters}

The sampled seawater was characterized by a salinity of 20-33 (ppt) and varying $\mathrm{pH}$ of $6.7-8.20$ (Table 6). The standard $\mathrm{pH}$ for seawater is $6.5-8.5$ and the values obtained from these samples were within the reported values. The variation of temperature was $29-32^{\circ} \mathrm{C}$. The lowest dissolved oxygen (DO) value recorded for seawater was $6.86 \mathrm{mg} / \mathrm{L}$, while the highest was $8.6 \mathrm{mg} / \mathrm{L}$ (Table 6). Generally, the dissolved oxygen will be affected by water temperature, tides and water depths.

Table 6. Variation of physical parameters in seawater and sand.

\begin{tabular}{lll}
\hline Parameter & Seawater & Sand \\
\hline DO $(\mathrm{mg} / \mathrm{L})$ & $6.9-8.6$ & - \\
$\mathrm{pH}$ & $6.7-8.2$ & $7.5-8.2$ \\
Temperature $\left({ }^{\circ} \mathrm{C}\right)$ & $29-32$ & $29-32$ \\
Conductivity $\left(\mathrm{x} 10^{3}\right)(\mu \mathrm{S} / \mathrm{cm})$ & $24.1-49.4$ & $1.55-2.8$ \\
TDS $(\mathrm{mg} / \mathrm{L})$ & $18.4-37.8$ & $807-1827$ \\
Salinity $\left(\mathrm{ppt}^{*}\right)$ & $22-33$ & $0.8-1.8$ \\
\hline
\end{tabular}


This study provided an opportunity to observe the levels of different indicator organisms in seawater in this selected site. It also showed that use of multiple indicator organisms to assess the microbiological quality of seawater may classify the water into different categories on the basis of the selected indicator organism. Due to these discrepancies observed among the different indicator organisms, it appears further studies are required before selecting the microbiological classification levels of a beach area. Additional studies should be carried out on identifying the different sources of contamination such as discharge of wastewater, runoffs etc. and/or epidemiological studies. Microbial source tracking studies are also useful to determine whether the selected indicator organisms are of animal, human or environmental origin.

\section{Conclusions}

The present work represents the initial study of seawater quality in the selected beach site, which is a popular bathing site. Based on the bacterial indicator enterococci, this particular study site was provisionally classified into D grade level as per WHO guide. In comparison with seawater, the total coliforms and Enterococcus spp. were high in sand, but $E$. coli was high in seawater. The results also indicated that the presence of Aeromonas was high in sand but low in seawater. Bacillus spp. was the dominating organisms in seawater.

\section{Acknowledgements}

The authors express their appreciation to Ms. KPR Priyadarshani (Department of Microbiology, University of Kelaniya) and Mr. HP Weerarathna (Department of Zoology and Environmental Management, University of Kelaniya) for their technical support.

\section{References}

[1] C. M. Davies, J. A. H. Long, M. Donald and N. J. Ashbolt, "Survival of fecal microorganisms in marine and freshwater sediments," Appl. Environ. Microbiol., vol. 61(5), pp. 1888 1896,1995

[2] S. Andraus, I. C. Pimentel and J. A. Dionísio, "Microbiological monitoring of seawater and sand of beaches Matinhos, Caiobá e Guaratuba-PR, Brazil," Estudos de Biologia, 36 (86), pp. 43-55, 2014.

[3] E. Velonakis, D. Dimitriadi, E. Papadogiannakis and A. Vatopoulos, "Present status of effect of microorganisms from sand beach on public health," Journal of Coastal Life Medicine, vol. 2 (9), pp. 746-756, 2014.

[4] G. Costaa, G. Caladob, F. Errab, M. Freitasa, K. Krehla and M. A. A. Pinheiro de Carvalhoc, "Microbiology Water Quality of Three Coastal Beaches at Madeira Island, Atlantic Ocean," Hydrology: Current Res., vol. 5 (3), pp. $1-5,2014$.
[5] S. A. Anderson, S. J. Turner and G. D. Lewis, "Enterococci in the New Zealand Environment: Implications for water quality monitoring," Water Sci. Technol., vol. 35 (11-12), pp. 325$331,1997$.

[6] C. Nelson and A. T. Williams, "Bathing Water Quality and Health Implications," Transactions on Ecology and the Environment, vol. 14, pp. 176-183, 1997.

[7] E. Halliday, S. L. McLellan, L. A. Amaral-Zettler, M. L. Sogin and R. J. Gast, "Comparison of bacterial communities in sands and water at beaches with bacterial water quality violations," PLOS ONE, vol. 9 (3), pp. 1-9, 2014.

[8] WHO, "Guidelines for Safe Recreational-Water Environments," Coastal and Fresh-Water, WHO/EOS/98.14, vol. 1, World Health Organization, Geneva, 1998.

[9] J. M. Fleisher, D. Kay, L. Roland, M. F. P. H. M. Salmon, F. Jones, M. D. Wyer and A. F. Godfree, "Marine waters contaminated with domestic sewage: Nonenteric illnesses associated with bather exposure in the United Kingdom," American Journal of Public Health, vol.86 (9), pp. 1228-1234, 1996.

[10] WHO, "Guidelines for Safe Recreational-Water Environments," Coastal and Fresh-Water, vol. 1., World Health Organization, Geneva, 2003.

[11] US-EPA, "Water Quality Standards for Coastal and Great Lakes Recreation Waters-Final Rule, (Part II) EPA- 40 CFR Part 131, U. S. Environmental Protection Agency, Washington, DC, 2004.

[12] R. H. S. F. Vieira, D. P. Rodrigues, E. A. Menezes, N. S. S. Evangelista, E. M. F. dos Reis, L. M. Barreto and F. A. Gonclaves, "Microbial contamination of sand from major beaches in Fortaleza Ceara State, Brazil, " Brazilian Journal of Microbiology, vol. 32, pp. 77-80, 2001.

[13] C. Crabill, R. Donald, J. Snelling, R. Foust and G. Southam, "Impact of sediment fecal coliform reservoirs on seasonal water quality in Oak Creek, Arizona," Water Res., vol.33 (9), pp. 2163-2171, 1999.

[14] A. A. Elmanama, M. I. Fahd, S. Afifi, S. Abdallah and S. Bahr, "Microbiological beach sand quality in Gaza Strip in comparison to seawater quality," Environmental Res., vol.99, pp. 1-10, 2005.

[15] A. Ahmad, A. C. Dada, G. Usup and L. Y. Heng, "Validation of the Enterococci indicator for bacteriological quality monitoring of beaches in Malaysia using a multivariate approach," Springer plus, vol.2: 425, pp 1-18, 2013.

[16] F. Curiel-Ayala, E. Quiñones-Ramírez, R. Pless and E. González-Jasso, "Comparative studies on Enterococcus, Clostridium perfringens and Staphylococcus aureus as quality indicators in tropical seawater at a Pacific Mexican beach resort," Mar. Pollut. Bull., vol. 64 (10), pp. 2193 2198,2012

[17] R. Sabino, R. Rodrigues, I. Costa, C. Carneiro, M. Cunha, A. Duarte, N. Faria, F. C. Ferreira, M. J. Gargaté, C. Júlio, M. L. Martins, M. B. Nevers, M. Oleastro, H. Solo-Gabriele, C. Veríssimo, C. Viegas, R. L. Whitman, and J. Brandão,"Routine screening of harmful microorganisms in beach sands: Implications to public health," Science of the Total Environment, vol.472. pp. 1062-1069, 2014. 
[18] M. I. Z. Sato, M. Di Bari, C. C. Lamparelli, A. C. Truzzi, M. C. L. S. Coelho, and E. M. Hachich, "Sanitary quality of sands from marine recreational beaches of São Paulo, Brazil," Brazilian Journal of Microbiology, vol.36, pp. 321326, 2005.

[19] B. Mendes, J. Nascimento, P. Urbano, C. Alves, N. Lapa, and J. S. Oliveira, "Microbiological quality of the sand beaches in Portugal," Transactions on Ecology and the Environment, vol. 9, pp. 181-190, 1996.

[20] A. M. T. B. Alahakoon, S. C. Jayamanne, M. S. Kurukulasuriya, and A. J. M. Gunasekara, "Assessment of Microbiological Water Quality in West Coast Sea Bathing Sites of Sri Lanka," Proceedings of the First International Symposium on Environmental Management and Planning, 25, 2015.

[21] APHA, "Microbiological examination of water. In: Standard Methods for the Examination of Water and Wastewater," $19^{\text {th }}$ ed., American Public Health Association, American Water Works Association, and Water Environment Federation. Washington, DC, 1995.

[22] UNEP, "Determination of total coliforms in sea water by the multiple test tube (MPN) method," Reference methods for Marine Pollution Studies, No. 21 Rev. 1, 1995.

[23] G. Tugrul-Icemer, and A. Topaloglu, "Levels of Yeast Mold and Pseudomonas spp. in Antalya Beaches," Journal of Coastal Research, vol. SI 61, 452-457, 2011.

[24] D. H Bergey, N. R. Krieg and J. G. Holt, "Bergey's manual of systematic bacteriology," vol.1, Williams and Wilkins Baltimore USA, 1984

[25] P. H. A. Sneath, N. S. Mair, M. E. Sharpe and J. G. Holt, "Bergey's manual of systematic bacteriology," vol.2, Publisher Williams and Wilkins Baltimore USA, 1986.

[26] G. Barrow, R. K. A. Felthman, "Cowan and Steel's manual for the identification of medical bacteria," Cambridge University Press. 2003

[27] M. Dworkin, S. Falkow, E. Rosenberg, K. H. Schleifer and E. Stackebrandt, "The Prokaryotes - A hand book on the Biology of Bacteria - Firmicutes, Cyanobacteria," vol.4, Published by Springer, 2006a.

[28] M. Dworkin, S. Falkow, E. Rosenberg, K. H. Schleifer and E. Stackebrandt, "The Prokaryotes - A hand book on the Biology of Bacteria - Proteobacteria: Gamma Subclass," vol.6, Published by Springer, 2006b.

[29] W. F. Harrigan and M. E. McCance, "Laboratory methods in food and dairy microbiology," Academic Press, London, 1976.

[30] Department of Meteorology, Sri Lanka, 2015. (www.meteo.gov.lk)

[31] US-EPA, "Ambient water quality criteria for bacteria," EPA A440/5-84-002, U.S. Environmental Protection Agency, Washington, DC, 1986.

[32] M. N. Byappanahalli, M. B. Nevers, A. Korajkic, Z. R. Staley, and V. J. Harwood, "Enterococci in the Environment," Microbiology and Molecular Biology Reviews, vol.76 (4), pp. 685-706, 2012.

[33] T. Shibata, H. M. Solo-Gabriele, L. E. Fleming, and S. Elmir, "Monitoring marine recreational water quality using multiple microbial indicators in an urban tropical environment," Water Res., vol. 38, pp. 3119-3131, 2004.

[34] E. N. Ribeiro, A. B. dos Santos, R. F. Gonçalves, and S. T. A. Cassini, "Recreational water and sand sanitary indicators of Camburi beach, Vitoria, Es., Brazil," 2002. (http://www.bvsde.paho.org/bvsaidis/mexico26/ix-032.pdf).

[35] R. T. Nobel, D. F. Moore, M. K. Leecaster, C. D. McGee, and S. B. Weisberg "Comparison of total coliform, fecal coliform, and enterococcus bacterial indicator response for ocean recreational water quality testing," Water Res., vol.37(7), pp. $1637-1643,2003$

[36] R. T. Nobel, I. M. Lee and K. C. Schiff, "Inactivation of indicator microorganisms from various sources of faecal contamination in seawater and freshwater," J. Appl. Microbiol., vol.96, pp. 464-472, 2004.

[37] Y. Yoshpe-purer and S. Golderman, "Occurrence of Staphylococcus aureus and Pseudomonas aeruginosa in Israeli coastal water," App. Environ. Microbiol., vol. 53 (5), pp. 1138-1141, 1987.

[38] M. Solic and N. Krstulovic, "Role of predation in controlling bacterial and heterotrophic nanoflagellates standing stocks in the coastal Adriatic Sea: seasonal patterns," Mar. Ecol. Prog. Se, vol.114, pp. 219-235. 1994.

[39] A. B. Boehm, J. Griffith, C. McGee, T. A. Edge, H. M. SoloGabriele, R. Whitman, Y. Cao and M. Getrich, J. A. Jay, D. Ferguson, K. D. Goodwin, C. M. Lee and S. B. Weisberg, "Fecal indicator bacteria enumeration in beach sand: a comparison study of extraction methods in medium to coarse sand," J. Appl. Microbiol., vol. 107 (5), pp. 1740-1750, 2009.

[40] M. C. Phillips, H. M. Solo-Gabriele, A. M. Piggot, J. S. Klaus and Y. Zhang, "Relationships between sand and water quality at recreational beaches," Water Res., vol.45(20), pp. 6763 $6769,2011$.

[41] A. M. Piggot, J. S. Klaus, S. Johnson, M. C. Phillips, and H. M. Solo-Gabrirle, "Relationship between Enterococcal levels and Sediment Biofilms at Recreational Beaches in South Florida," Appl. Environ. Microbiol., vol. 78 (17), pp. 59735982, 2012.

[42] K. M. Yamahara, B. A. Layton, A. E. Santoro, and A. B. Boehm, "Beach sands along the California coast are diffuse sources of fecal bacteria to coastal waters," Environ. Sci. Technol. vol.41, pp. 4515-4521, 2007.

[43] S. M. Elmir, M. E. Wright, A. Abdelzaher, H. M. SoloGabriele, L. E. Fleming, G. Miller, M. Rybolowik, M. P. Shih, S. P. Pillai, J. A. Cooper, and E. A. Quaye, "Quantitative evaluation of bacteria released by bathers in a marine water," Water Res. vol.41 (1), pp. 3-10, 2007.

[44] G. Brandi, M. Sisti, F. Giardini, G. F. Schiavano, and A. Albano, "Survival ability of cytotoxic strains of motile Aeromonas spp. in different types of water," Lett. Appl. Microbiol., vol.29, pp. 211-215, 1999.

[45] K. Krovacek, V. Pasquale, S. B. Baloda, V. Sopraro, M. Conte, and S. Dumontet, "Comparison of putative virulence factors in Aeromonas hydrophila strains isolated from the marine environment and human diarrheal cases in Southern Italy," Appl. Environ. Microbiol., vol. 60 (4), pp. 1379-1382, 1994. 
[46] S. Maalej, A. Mahjoubi, C. Elazri, and S. Dukan, "Simultaneous effects of environmental factors on motile Aeromonas dynamics in an urban effluent and in the natural seawater," Water Res., vol.37 (12), pp. 2865-2874, 2003.

[47] A. P. Delamare, S. O. Costa, M. M. Da Silveira, and S. Echeverrigaray, "Growth of Aeromonas species on increasing concentrations of sodium chloride," Lett. Appl. Microbiol., vol.30, pp. 57-60, 2000.
[48] C. R. Arias, M. C. Macian, R. Aznar, E. Garay, and M. J. Pujalte, "Low incidence of Vibrio vulnificus among Vibrio isolates from sea water and shellfish of the western Mediterranean coast," J. Appl. Microbiol., vol.86, pp. 125134, 1999. 